\title{
EFFECT OF RICE STRAW BIOCHAR AND COMPOST APPLICATION AT DIFFERENT RATIOS ON HEAVY METALS IMMOBILIZATION IN THE CANOLA PLANTS GROWN IN CONTAMINATED SOIL
}

\author{
E. K. Mahmoud ${ }^{(1)^{*}}$, M. M. Ibrahim ${ }^{(1)}$, Nehal Ali ${ }^{(2)}$ \\ and Hanan M. Ali ${ }^{(1)}$ \\ (1) Department of soil and water science, Faculty of agriculture, Tanta University, Egypt \\ (2) Department of Engineering Physics and Mathematics, Faculty of Engineering, Tanta \\ University, Egypt \\ * Corresponding author email: esawy.rezk@agr.tanta.edu.eg \\ Tel No: +20403455584 Fax No: +20403455570 \\ Postal address: Soil and water department, faculty of agriculture, University of \\ Tanta, Egypt. P.O. Box: 31527 Tanta, Egypt.
}

Received: Apr. 3, 2018

Accepted: Apr. 19, 2018

\begin{abstract}
Industrial activities can contribute to the heavy metal accumulation in soils, which could potentially threaten human health, agricultural crop productivity and the environment. This research was conducted to use metal uptake and spectroscopic analysis (X-Ray Diffraction (XRD), Energy Dispersive spectroscopy by X-rays (EDX) and Fourier Transmission Infrared Spectroscopy (FTIR) to evaluate the effect of application of both rice straw biochar and compost with different ratios on heavy metal immobilization in the canola plants grown in the contaminated soil. The results showed that the $\mathrm{Cd}, \mathrm{Pb}$, $\mathrm{Ni}$ and $\mathrm{Zn}$ uptake in the root and shoot of canola plants significantly decreased with the addition of rice straw compost (RC) and biochar (RB) to contaminated soil. The addition of $1 \%$ mixture of RC and RB gives the most effective immobilizing metals as $100 \%$ and 74.2\%, reduction in $\mathrm{Cd}$ and $\mathrm{Pb}$ accumulation by canola shoots, respectively. The biochar and compost obtained from rice straw showed high carbon content, silica and a high absorption character. The use of spectroscopic analysis observed the precipitation, inner-sphere complex reaction and electrostatic attraction are the dominating mechanism for heavy metal immobilization with organic amendments. Our results indicate that the metal uptake is considered to be the effective tool to assess the efficiency of immobilizing agents on metal phyto-availability.
\end{abstract}

Key words: Rice straw biochar; Rice straw compost; Heavy metals; Spectroscopic analysis; Canola plants.

\section{INTRODUCTION}

Heavy metal contamination due to geological and anthropogenic activities is a widespread environmental problem with serious consequences for human health and agricultural crop productivity. These activities include atmospheric deposition of emissions from industrial processes, mining, sewage sludge application, and use wastewater in irrigation (Alloway 1990 and Neilson and Rajakaruna 2014). Heavy metals cannot be destroyed biologically, are non degradable, and are toxic to living organisms (Nriagu 1991). Furthermore, some heavy metals are accumulated in plant tissue or grains and when transferred to the food chain may adversely affect their health (Kelly et al. 1996). Uptake of Cd by carrot roots was about five times more than the regulatory limits for men, eight times more for women, and 12 times more for children when it's grown in soils from Spelter, 
WV, USA, contaminated with a variety of metals including lead (Pb), zinc ( $\mathrm{Zn})$, cadmium (Cd), and copper $(\mathrm{Cu})$. From this result, carrot and lettuce grown in these soils have the potential to cause toxicological problems for men, women, and young children due to $\mathrm{Cd}$ and $\mathrm{Zn}$ accumulation (Roy and McDonald 2015). In a study carried out by EL- Shall (2010) on Kafer El- Zaiyat soils in Egypt. These soils received atmospheric emissions from the adjacent factories and irrigated from some polluted drains, the amounts of heavy metals in these soils were very high and reached more than the permissible limits. Abd El- Salam (1994) showed that in both soils surrounding Alexandria Factory for soap and El- Suif Electric Power Station; the soil pollution by heavy metals is dependent on the distance from the pollution source, type of pollutant, soil properties and the agronomic practices.

Soil remediation technologies of heavy metals such as soil solidification, excavation, land filling, and washing strategies can be an expensive and arduous task (Mulligan et al., 2001 and Sruthy and Jayalekshmi 2014). As an alternative, in situ techniques such as immobilization of heavy metals can potentially be lower in cost and reduce the impact on the ecosystem than land filling, excavation and other soil remediation (Vangronsveld and Cunningham 1998). Heavy metals immobilization in contaminated soils can be remediated by biological, physical and chemical techniques (Bolan et al., 2003). Heavy metal immobilization involves the addition of amendments to contaminated soils can reduce mobility and toxicity of metals through metal sorption and precipitation (Adriano et al., 2004). Also, carbon-rich amendments such as compost (RC) and biochar (RB) have been used as a novel carbonaceous material and economically feasible technologies to adsorb metals in soil and water (Houben et al., 2013a, b and Almaroai et al., 2014). RB is produced by parolysis of organic wastes under low oxygen conditions. It is capable of improving chemical, biological, and physical properties in soils due to its high organic carbon content (Almaroai et al., 2014). Incorporation of biochar into soil leads to increases in soil organic matter, soil fertility, and enhances plant growth (Houben et al., 2013b and Mahmoud et al., 2016). Green waste biochar application to spiked soils significantly reduced the phytoavailability of $\mathrm{Pb}, \mathrm{Cu}$, and $\mathrm{Cd}$ in Indian mustard (Brassica juncea (L.) Czern) and other plants (Park et al., 2011). Orchard prune residue biochar application to contaminated soil significantly increased arsenic (As) concentrations in soil pore water, while shoot and root concentrations were significantly reduced compared to the control without biochar in a pot experiment. Moreover, concentrations in fruit were very low, indicating minimal toxicity and transfer risk (Hartley et al., 2009). The application of biochar has been recommended as a sustainable means to promote the revegetation and the restoration of degraded lands (Beesley et al., 2011 and Fellet et al., 2011). The addition of rice straw compost to contaminated soil decreased $\mathrm{Cd}, \mathrm{Zn}$ and $\mathrm{Pb}$ concentrations in the shoot and root of canola plants (Mahmoud 2011 and Mahmoud and Abd El-Kader 2014). Parka et al. (2011) found that, the ability of spending mushroom composts to decrease $\mathrm{Pb}, \mathrm{Cd}$ and $\mathrm{Zn}$ accumulation in perennial rye-grass were related to the presence of phenolic and hydroxyl groups. Composts are rich in functional groups such as amino, carbonyl and hydroxyl groups were effective in heavy metal immobilization because of its ability to bind or complex metal (Basta et al., 2005). 
The adsorption mechanisms for heavy metals by biochar involved electrostatic attraction, precipitation on biochar and formation of complexes between metals and functional groups on biochar (Dong et al., 2013 and Lu et al., 2012). Heavy metals sorption by biochar or compost was mostly through the formation of surface complexes between these metals and $-\mathrm{OH}$ or $-\mathrm{COOH}$ groups (Tong et al., 2011and Jiang et al., 2012). Heavy metals sorption on the functional groups such as - $\mathrm{COOH}$, phenolic - $\mathrm{OH}$ or alcoholic $\mathrm{OH}$ groups may involve inner-sphere surface complexation and electrostatic attraction (Cao and Harris, 2010). Cao et al. (2011) observed by XRD analysis that dairy manure biochar contains high levels of available $P$, which may able to immobilize $\mathrm{Pb}$ in soils by forming insoluble hydroxypyromorphite $\mathbf{( P b}_{5}$ $\left.(\mathrm{PO} 4)_{3}(\mathrm{OH})\right)$. Cao and Harris (2010) found that the increasing of available $\mathrm{P}, \mathrm{Mg}$, and $\mathrm{Ca}$ of biochars is associated with high $\mathrm{Pb}$ stabilization in the form of carbonates, phosphates or oxides.

Canola (Brassica napus) is one of the most promising, hyper-accumulating plant species for heavy metals from contaminated soils (Gisbert et al., 2006). Schmidt (2003) showed that corn (Zea mays L.), Indian mustard (Brassica juncea) or sunflower (Helianthus annuus L.) plants were high tolerance to heavy metals and therefore, can be recommended for planting in contaminated soils. Biochar and phytoremediation techniques have been used recently to soil remediation (Houben et al., 2013b) using Brassica napus L. with Miscanthus biochar addition to multicontaminated soils (Fellet et al., 2014). The application of biochar to metal-contaminated soils could thus serve two purposes: to improve the soil conditions thereby allowing energy biomass and biofuel production, and to sequester $C$ by burying part of the produced biomass (Houben et al., 2013)
The present study was conducted to use metal uptake by canola plants and spectroscopic analysis to evaluate the effect of application of both rice straw biochar and compost with different ratios on heavy metal immobilization from the contaminated soil.

\section{MATERIALS AND METHODS}

\section{Basic of the soil studied}

Fifteen composite soil samples after mixed were collected at a depth of 0 to 20 $\mathrm{cm}$ from agricultural farms of the Middle Nile Delta, at Kafer El- Zaiyat area (lat. $30^{\circ}$ $\left.40^{`} \mathrm{~N}, 30^{\circ} 43^{`} \mathrm{E}\right)$ El-Gharbia Governorate, Egypt. The soils of the studied area were classified as a Vertic Torrifluvents. The soil moisture regime of the studied area could be defined as Torric and soil temperature regime as Thermic according to EL- Shall (2010). The source of soil pollution in the studied area is mainly atmospheric emissions of the adjacent factories and irrigation from some polluted drains. These soils were contaminated with $\mathrm{Cd}, \mathrm{Pb}, \mathrm{Ni}$, and $\mathrm{Zn}$ where the total concentrations exceed 10 , 260,350 , and $300 \mathrm{mg} \mathrm{kg}^{-1}$ soil, respectively (EPA, 1993). Soil samples were dried in air and then crushed to pass through a 2-mm sieve. Chemical and physical analyses of the five composite soil samples were determined using the standard methods undertaken by Black et al. (1983) and Page (1982) and data are presented in (Table 1).

\section{Biochar and compost production}

The biochar (RB) used in this experiment was prepared from rice straw from a local producer using a batch pyrolysis facility at a final temperature $\left(400{ }^{\circ} \mathrm{C}\right)$ with to 2 hours retention time. Biochar samples were ground and sieved $<0.5 \mathrm{~mm}$, prior to be used and characterized. It is found that biochar product had high organic carbon of $62.5 \%$. This value was characterized by electrical conductivity (EC) of $2.45 \mathrm{dS} \mathrm{m}^{-1}$

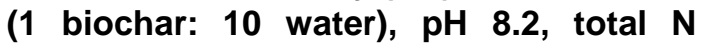
$1.38 \%$, total $P 0.65 \%$, total K $1.18 \%$ and cation exchange capacity (CEC) of $\mathbf{3 2 . 4 2}$ $\mathrm{cmol} \mathrm{kg}^{-1}$ biochar. 
E. K. Mahmoud, et al.,

Table (1): Chemical and Physical characteristics of studied soil.

\begin{tabular}{|c|c|}
\hline Properties & Soil \\
\hline $\mathrm{pH}$ & 8.31 \\
\hline$E C\left(d S ~ m^{-1}\right)$ & 5.47 \\
\hline \multicolumn{2}{|l|}{ Soluble ions $\left(\mathrm{meq} \mathrm{L}^{-1}\right)$} \\
\hline $\mathrm{Ca}^{++}$ & 5.70 \\
\hline $\mathrm{Mg}^{++}$ & 4.89 \\
\hline $\mathrm{Na}^{+}$ & 39.00 \\
\hline $\mathrm{K}^{+}$ & 0.10 \\
\hline $\mathrm{Cl}^{-}$ & 31.25 \\
\hline $\mathrm{HCO}_{3}{ }^{-}$ & 10.20 \\
\hline $\mathrm{SO}_{4}^{--}$ & 10.79 \\
\hline \multicolumn{2}{|c|}{ Exchangeable cations $\left(\mathrm{c} \mathrm{mol}_{(+)} \mathrm{kg}^{-1}\right.$ ) } \\
\hline $\mathrm{Ca}^{++}$ & 12.20 \\
\hline $\mathrm{Mg}^{++}$ & 4.03 \\
\hline $\mathrm{Na}^{+}$ & 11.46 \\
\hline $\mathrm{K}^{+}$ & 2.89 \\
\hline CEC & 30.58 \\
\hline ESP (\%) & 37.47 \\
\hline \multicolumn{2}{|l|}{ NPK available $\left(\mathrm{mg} \mathrm{kg}^{-1}\right)$} \\
\hline $\mathbf{N}$ & 36.18 \\
\hline $\mathbf{P}$ & 17.64 \\
\hline $\mathbf{K}$ & 193.58 \\
\hline \multicolumn{2}{|l|}{ NPK total (\%) } \\
\hline $\mathbf{N}$ & 0.98 \\
\hline $\mathbf{P}$ & 0.198 \\
\hline $\mathrm{K}$ & 0.20 \\
\hline O.M \% & 1.36 \\
\hline \multicolumn{2}{|l|}{ Particle size distribution } \\
\hline Clay & 24.99 \\
\hline Silt & 41.23 \\
\hline Sand & 33.78 \\
\hline Texture & Clay loam \\
\hline Bulk density $\left({\left.\mathrm{g} . \mathrm{cm}^{-3}\right)}^{-3}\right.$ & 1.33 \\
\hline \multicolumn{2}{|l|}{ Total heavy metal $\left(\mathrm{mg} \mathrm{kg}^{-1}\right)$} \\
\hline $\mathrm{Pb}$ & 495 \\
\hline Cd & 105 \\
\hline$Z n$ & 512 \\
\hline $\mathrm{Ni}$ & 648 \\
\hline
\end{tabular}


The compost (RC) used in this experiment was prepared from rice straw and animal wastes. Rice straw was mixed with animal wastes in turned piles to give a $\mathrm{C} / \mathrm{N}$ ratio (30-35) as recommended for composting process. Composting piles were remained for 12 weeks after that produced compost. Its organic carbon ratio is $23.7 \%$, and characterized by electrical conductivity (EC) of $4.36 \mathrm{dS} \mathrm{m}^{-1}$ (1 compost:10 water), $\mathrm{pH} 7.21$, total of $\mathrm{N}$ $1.42 \%, \mathrm{P} 0.34 \%, \mathrm{~K} 0.8 \%, \mathrm{Ca}^{++} 1.2 \%$, and $\mathrm{Mg}^{++} 0.9 \%$.

\section{Set up of experiment}

Canola (Brassica napus) was sown in plastic pots under greenhouse conditions in a completely randomized experimental design with five replicates. The treatments were untreated soil (CT) and soil treated with two rates of rice straw compost (RC) and rice straw biochar (RB), and RC+RB (1:1 wet weight ratio) applications. Soil was amended by mixing dry $\mathrm{RC}$ and $\mathrm{RB}$ with a mass fraction of 0.5 and $1.0 \%$. (w/w). Each plastic pot contained $4 \mathrm{~kg}$ soil from a composite soil sample after of air dried and passing through an $8 \mathrm{~mm}$ sieve to reflect natural soil conditions. The soil portions were uniformly mixed with the $\mathrm{RC}$ and RB, and packed in the plastic pots of $18 \mathrm{~cm}$ diameter and $15 \mathrm{~cm}$ height. Nitrogen fertilizer was added in two equal doses as after 20 and $\mathbf{4 5}$ days of planting $\mathrm{NH}_{4} \mathrm{NO}_{3} 33.5 \% \mathrm{~N}$ at the rate of $143 \mathrm{~kg} \mathrm{ha}^{-1}$ and a basal dose of phosphorus was applied as superphosphate $15 \% \mathrm{P}_{2} \mathrm{O}_{5}$ at the rate of $357 \mathrm{~kg} \mathrm{ha}^{-1}$. The amount of irrigation water was measured by weighting the plastic pots to raise the moisture content to the field capacity of each treatment, with the addition to $10 \%$ as leaching requirement. Twenty days after planting, plants of each pots were thinned to three uniform plants per pot. Canola plant was harvested after 16 weeks from planting. Plants were washed and then dried at $65^{\circ} \mathrm{C}$ for $72 \mathrm{~h}$. The plant dry weight was recorded and the tissue ground to pass a $0.20-\mathrm{mm}$ sieve prior to analysis.

\section{Analysis of soil and amendments}

The EC and $\mathrm{pH}$ were measured in the soil paste extract with a $\mathrm{pH} /$ conductivity meter using a 1:10 biochar or compost: water ratio after stirring for $1 \mathrm{~h}$ and. The cations $\left(\mathrm{Na}^{+} \mathrm{Mg}^{++}, \mathrm{Ca}^{++}, \mathrm{K}^{+}\right)$and anions $\left(\mathrm{HCO}_{3}{ }^{-}\right.$and $\left.\mathrm{Cl}^{-}\right)$were determined in soil paste extract as described by Rhoades (1954). Organic matter (OM) of soil was estimated by multiplying the $\mathrm{OC}$ value by Van Bemmelen of 1.724 based on the assumption that $\mathrm{OM}$ contains $58 \%$ OC (Nelson and Sommers, 1996). While, the organic matter of compost and biochar was determined by combustion method (Page et al., 1982).

\section{Analysis of total heavy metals}

Total heavy metals concentration was measured by atomic absorption after wet digesting the air dried soil, compost and biochar digested in concentrated $\mathrm{H}_{2} \mathrm{SO}_{4}+$ $\mathrm{H}_{2} \mathrm{O}_{2}$ (Cotteine et al. 1982).

X-ray diffraction patterns of the samples of rice straw boichar (RB), rice straw compost (RC), and the soil treated with (RB+RC) at $1 \%$ were investigated using, (Defractometer APD 2000PRO) at $40 \mathrm{KV}$ and $40 \mathrm{~mA}$ with Cu-Ka radiation source. Two grams of each sample were granulated for powder diffraction. Continuous scanning mode of 2 was conducted from 15 to 70 with interval of 2 second measurement an interval. The scattering was minimized using planer exposure.

The functional groups of the samples of rice straw boichar (RB), rice straw compost ( $R C)$, and the soil treated with $(R B+R C)$ at $1 \%$ were examined by Fourier transmission infrared spectroscopy (FTIR) . These samples were mixed with $\mathrm{KBr}$ at a fixed ratio to form disks. FTIR was conducted in an atmosphere using 
TENSOR 27- by Bruker. A spectrum (600$4000 \mathrm{~cm}-1$ ) was collected with $4 \mathrm{~cm}^{-1}$ resolution.

The surface morphology of the biochar particles was studied using a scanning electron microscopy system JEOL (JSM-7610F FEG-SEM). Samples were first coated with a sputter coater with a conductive layer to minimize the charging. The characteristic $X$-rays were used to distinguish the element composition of the samples (using EDX, Energy Dispersive Spectroscopy by $X$ rays). The suitable detectors allow to analyze qualitatively and quantitatively the elemental composition of the spectra.

\section{Statistical analysis}

All treatments were conducted with three replicates. All of the data obtained were analyzed statistically using SAS software. Duncan's multiple range tests were used to compare the means of the treatments. Statistical significance level of $P<0.05$ was used in means comparison .

\section{RESULTS AND DISCUSSION}

\section{Characters of soil amendments}

a- Fourier Transmission Infra Red Spectroscopy (FTIR)

The FTIR spectrum of RB and RC shown in Fig. (1), contained absorption peaks represent many functional groups on their surface, which indicated potentially different capabilities for adsorption of heavy metals. The peaks at $756 \mathrm{~cm}^{-1}$ for RB and at $794 \mathrm{~cm}^{-1}$ for RC were assigned to $\mathrm{C}-\mathrm{H}$ bending aromatic $\mathrm{CH}$ out-of-plane deformation (Wu et al., 2012). Peak at $321 \mathrm{~cm}^{-1}$ is assigned to $C-$ C-C deformation vibrations, appeared on the RB surface. Bands at 876 for RB and $878 \mathrm{~cm}^{-1}$ for RC were assigned to $\mathrm{Al}-\mathrm{OH}-$ $\mathrm{Fe}$ and they represent stretching, res (Xu et al., 2000). The peaks around $1100 \mathrm{~cm}^{-1}$ in the RB and RC were standing for outof-plane bending of carbonates (Yuan et al., 2011) or Si-O-Si, O-P-O, C-OH and C$C$ stretching, and the band around 1592 $\mathrm{cm}^{-1}$ to -COO- anti-symmetric stretching in RB (Yuan et al., 2011) or aromatic $C=C$ (Luo et al. 2011). The peaks at 1647 for RC and 1797 for RB indicated C=C stretching and $\mathrm{C}=\mathrm{O}$ stretching, respectively. The bands at 2965 for RB and $2857 \mathrm{~cm}^{-1}$ for RC were assigned to $\mathrm{CH}_{2}$ and $-\mathrm{CH}_{3}$ groups of long-chain aliphatic components, respectively (Uchimiya et al. 2010). The bands at 3418 and $3417 \mathrm{~cm}^{-1}$ were attributed to the stretching vibrations of hydrogenbonded hydroxyl groups of BR and CR, respectively (Keiluweit et al., 2010 and Chen et al., 2008). BR, aromatic $C=C$ ring stretching was observed at $1433 \mathrm{~cm}^{-1}$. The sharp peak at $1090 \mathrm{~cm}^{-1}$ in RC was assigned to $\mathrm{C}-\mathrm{O}$ stretching of polysaccharides or polysaccharide-like substances. This peak decreased at 1086 for RB, which indicated that polysaccharide was destructed with pyrolysis of rice straw compost. The peaks assigned to oxygenate and alkyl function groups decreased in the biochar while, the aromaticties increased (Harvey et al. 2011). Comparison of the FTIR spectrum of metal contaminated soil with FTIR spectrum of metal contaminated soil amended with $R C+R B$ at $0.5 \%$ and $1.0 \%$ (Figure 2) shows a shit of Si-O stretching vibrations band at $1033 \mathrm{~cm}^{-1}$ to higher wave number at $526 \mathrm{~cm}^{-1}$ as a result of increasing $\mathrm{Si}$ content in the treatment owing to compost and biochar of rice straw addition. Also bands at $1653,1435,1033$ and $792 \mathrm{~cm}^{-1}$ were shifted to the higher wave numbers after metal contaminated soil amended with RC+RB at $1.0 \%$. In the same figure new peaks at $2979-1796 \mathrm{~cm}^{-1}$ appeared in soil treated with $\mathrm{RC}+\mathrm{RB}$ at $1.0 \%$ that is not found in the contaminated soil, which could be assigned to $\mathrm{C}=\mathrm{C}$ in-line deformation vibration or carbon dioxide. The results indicated that $\mathrm{Cd}, \mathrm{Zn}$ and $\mathrm{Pb}$ were adsorbed through the coordination 
Effect of rice straw biochar and compost application at different ratios on ..........

Fig 1 
E. K. Mahmoud, et al.,

Fig 2 
of metal electron to $\mathrm{C}=\mathrm{C}$ (m-electron) bond of compost and biochar, which resulted in the immobilization of heavy metals in soil.

The oxygen-containing functional groups have been reported that play important roles in the capacity of organic sorbents in the adsorption of heavy metals (Chen et al. 2008). The main mechanisms affecting adsorption of heavy metals are most probably an electrostatic attraction and complexation. Electrostatic attraction occurs between the compost and biochar surfaces and heavy metals present in the contaminated soil. Biochar and compost of rice straw also contain surface functional groups (e.g. carboxylate, hydroxyl, P-O, Si-O) as shown in the respective FTIR section. These functional groups may interact with heavy metal ions and form surface complexes on biochar and compost (Liang et al., 2006; Tong et al. 2011 and Xu et al. 2013). Han et al. (2013) reported that the removal of $\mathrm{Cd}^{2+}$ from aqueous solution by biochar of rice straw may be attributed to the formation of surface complexes between $\mathrm{Cd}$ and carboxylic-C and aromatic $\mathrm{OH}$ groups. These suggestions were confirmed as shown in the results of FTIR where in the soil treated with $(\mathrm{RC}+\mathrm{RB})$ at $1.0 \%$, the contents of $\mathrm{O}, \mathrm{Si}$, and $C$ were high. In the same sample, Al and $\mathrm{Fe}$ were presented in lesser quantities whereas $\mathrm{K}, \mathrm{Mg}, \mathrm{P}, \mathrm{Ca}$, and $\mathrm{S}$ show showed the lowest content.

\section{b- Scanning Electron Microscopy system (SEM)}

Figure (3) shows the SEM images of the soil treated with biochar and compost with two different magnification ratios to visualize the morphology of the surface and to show the homogeneous distribution of the additives in the soil. As shown in the images the surface seems to be comparatively rough and without cracks. Some beneficial porous texture is also observed due to thermal treatment in the biochar manufacturing process. The pores increase the capabilities of heavy metals adsorption (Jiang et al., 2012a).

\section{c-Energy Dispersive Spectroscopy by X-ray (EDX) \\ EDX spectrum of the control and the} soil treated with $R B+R C$ are shown in (Fig. 4). In the soil treated with (RC+RB) at $\mathbf{1 . 0 \%}$, elements as $\mathrm{O}, \mathrm{Si}$, and $\mathrm{C}$ have high content. In the same sample, Al and Fe have lesser quantities whereas $\mathrm{K}, \mathrm{Mg}$, $\mathrm{P}, \mathrm{Ca}$, and $\mathrm{S}$ have the lowest content. EDX has shown the dominant elements to be $\mathrm{C}, \mathrm{O}$, and $\mathrm{Si}$ whose percentage compositions are 41.19, 21.99, and $11.35 \%$, respectively. This analysis indicated that the mineral composition in the study areas was silica $\left(\mathrm{SiO}_{2}\right)$, alumina $\left(\mathrm{Al}_{2} \mathrm{O}_{3}\right)$, and iron (III) oxide $\left(\mathrm{FeO}_{3}\right)$. According to the previous studies, the presence of $\mathrm{P}, \mathrm{Si}, \mathrm{Al}$, and $\mathrm{O}$ in soil may be associated with the immobilization of Pb (Ahmad et al., 2012a and Moon et al., 2013). This fits well with the noticeable reduction in the content percentage of the $\mathbf{C d}$ and $\mathbf{P b}$ elements as shown in (Fig. 4) where the $\mathrm{Cd}$ is reduced by $35 \%$, while $\mathrm{Pb}$ is reduced by $82 \%$.

\section{d- X-Ray Diffraction (XRD)}

$X$-ray diffraction pattern of the samples of rice straw biochar (RB), rice straw compost (RC), and the soil treated with RB+RC are shown in (Fig. 5). The crystalline structure of the three samples is observed from the sharp peaks. The phase identity of the soil treated with RB+RC confirms the homogeneous mixing and show a dominant crystals form of quartz $\left(\mathrm{SiO}_{2}\right)$, and calcite $\left(\mathrm{CaCO}_{3}\right)$ which existence may relate to the alkalinity of the rice straw products. Also the presence of sylvite $(\mathrm{KCl})$, struvite $\left(\mathrm{KMgPO}_{4} .6 \mathrm{H}_{2} \mathrm{O}\right)$, and whitelokite $\mathrm{Ca}_{9}$ $(\mathrm{MgFe})\left(\mathrm{PO}_{4}\right) 6 \mathrm{PO}_{3} \mathrm{OH}$ were confirmed. 
E. K. Mahmoud, et al.,

Fig 3 
Effect of rice straw biochar and compost application at different ratios on ..........

Fig 4 
E. K. Mahmoud, et al.,

Fig 5 
Some organic components were observed at lower diffraction angles; as crystalline cellulose and at some extent of such degrees the development of aromatic order in the carbonized samples was existed. Moreover, the crystalline peaks reveal the presence of $\mathrm{Cd}$ composites as cadmium sulfide (CdS) and cadmium carbonate $\left(\mathrm{CdCO}_{3}\right)$ as well as $\mathrm{Pb}$ composites in the form of anglesite $\left(\mathrm{PbCO}_{3}\right)$, cerussite $\left(\mathrm{PbSO}_{4}\right)$ and hydroxypyromorphite $\left(\mathrm{Pb}_{5}\left(\mathrm{PO}_{4}\right)_{3}(\mathrm{OH})\right)$ in the soil treated with biochar and compost.

\section{Dry weight of canola plants}

Application of compost, biochar individually and incommbination had a significant effect on dry weight of canola plants (Table 2). Dry weight of canola plants was increased by RC and RB, although differences between the $0.5 \%$ and $1.0 \%$ rate were not statistically significant. The additive ratio of $0.5 \%$ compost $+0.5 \%$ biochar gives the highest increase in the dry weight. The application of compost or biochar improved soil chemical and physical properties, which together were reflected on the dry weight and this effect was increased when compost was combined with biochar. Compost and biochar provide both NPK and other nutrients for growing canola plants (Asagi et al., 2007).

\section{Metal Phytovailability}

Lead $(\mathrm{Pb})$ and cadmium ( $\mathrm{Cd}$ ) uptake ( $\mathrm{mg} / \mathrm{kg}$ ) by canola roots significantly decreased with biochar and compost mixtures addition at percentage of $1 \%$ (Table 2), Also, $\mathrm{Cd}$ and $\mathrm{Pb}$ of biochar and compost uptake by canola roots decreased with increasing addition rates of biochar and compost, where $\mathrm{Pb}$ uptake of the roots decreased by 15.7 and $22.4 \%$ for RB, and by 30.8 and 42.9 $\%$ for RC with addition ratios of $0.5 \%$ and $1.0 \%$, respectively, compared to the control (Table 2). Similar results were obtained by Zheng et al. (2017) who found that the addition of rice straw biochar reduced uptake of $\mathrm{Cd}$ in lettuce shoots in the polluted soils. $\mathrm{Ni}$ and $\mathrm{Zn}$ uptake in the root of canola plants varied between the treatments, to reach its lowest values with the addition of biochar and compost mixtures. Treatments of RB or RC, uptake of $\mathrm{Zn}$ and $\mathrm{Ni}$ was not significantly influenced. As compared to control treatment, reduction of $\mathrm{Ni}$ and $\mathrm{Zn}$ uptake of the canola roots were significantly enhanced with the addition ratio of $1.0 \%$ of $(R C+R B)$ treatment. However, no significant decreases were obtained in $\mathrm{Ni}$ and $\mathrm{Zn}$ uptake of the canola roots following the application of RC and RB at $0.5 \%$ (Table 2). Ni uptake of the roots decreased by 8.6 and $30.1 \%$ for RB, and 6.9 and $11.2 \%$ for RC by 0.5 and $1.0 \%$ of applications, respectively, compared to the control.

The treatments of RC, RB and their mixtures show remarkable reduction effect of $\mathrm{Cd}$ and $\mathrm{Pb}$ uptake by canola shoots (Table 2), this effect increases with the increase of application. Reduction in $\mathrm{Pb}$ accumulation by canola shoots was 46.5 and $48.4 \%$ for rice straw compost, and 15.5 and $36.2 \%$ for rice straw biochar at 0.5 and $1.0 \%$ addition, respectively. Similar results agree with Lu et al. (2014), who found that the application of rice straw biochar reduced the concentration of $\mathrm{Cd}, \mathrm{Pb}$ and $\mathrm{Zn}$ in the shoots of Sedum plumbizincicola plant growth in a sandy loam paddy soil naturally co-contaminated with $\mathrm{Cd}, \mathrm{Cu}$, $\mathrm{Pb}$ and $\mathrm{Zn}$.

The results showed that, the addition of $1 \%$ mixture of $\mathrm{RC}$ and $\mathrm{RB}$ gives the most effective immobilizing metals as $100 \%$ and $74.2 \%$, reduction in $\mathrm{Cd}$ and $\mathrm{Pb}$ accumulation by canola shoots, respectively (Table 2 ). 
Table (2): Effect of compost and biochar on heavy metals uptake $\left(\mathrm{mgkg}^{-1}\right)$ in root and shoot canola plants

\begin{tabular}{|c|c|c|c|c|c|c|c|c|c|c|}
\hline \multirow{2}{*}{\multicolumn{2}{|c|}{ Treatments }} & \multirow{2}{*}{$\begin{array}{c}\text { Dry } \\
\text { weight } \\
\text { g pots }^{-1}\end{array}$} & \multicolumn{4}{|c|}{ Shoots } & \multicolumn{4}{|c|}{ Roots } \\
\hline & & & $\mathrm{Ni}$ & $\mathrm{Zn}$ & Cd & $\mathrm{Pb}$ & $\mathrm{Ni}$ & $\mathrm{Zn}$ & Cd & $\mathbf{P b}$ \\
\hline $\mathrm{C} 1$ & :T & $5.35^{\mathrm{c}}$ & $132.0^{\mathrm{a}}$ & $232.0^{\mathrm{a}}$ & $3.85^{b}$ & $177.5^{\mathrm{a}}$ & $62.5^{a}$ & $237.33^{\mathrm{a}}$ & $41.83^{a}$ & $197.5^{a}$ \\
\hline RB & $0.5 \%$ & $6.69^{a b c}$ & $130.0^{\mathrm{a}}$ & $229.53^{\mathrm{a}}$ & $4.46^{a b}$ & $113.3^{b}$ & $57.1^{a}$ & $233.5^{a}$ & $25.16^{b}$ & $167.0^{b}$ \\
\hline RB & $1.0 \%$ & $5.54^{b c}$ & $120.53^{b}$ & $219.0^{b}$ & $4.06^{b}$ & $150.0^{a}$ & $43.67^{b}$ & $233^{a b}$ & $18.0^{b c}$ & $153.33^{b c}$ \\
\hline RC & $0.5 \%$ & $8.01^{a}$ & $116.35^{b c}$ & $228.5^{\mathrm{ab}}$ & $4.60^{\mathrm{ab}}$ & $95.01^{b}$ & $58.16^{a}$ & $232.17^{\mathrm{ab}}$ & $14.83^{c}$ & $136.66^{\mathrm{cd}}$ \\
\hline $\mathrm{RC}$ & $1.0 \%$ & $7.51^{\mathrm{ab}}$ & $111.0^{c}$ & $223.5^{a b}$ & $4.35^{a b}$ & $91.66^{b}$ & $55.5^{a}$ & $230.5^{a b}$ & $18.5^{b c}$ & $112.67^{d}$ \\
\hline $\mathrm{RC}+\mathrm{RB}$ & В $0.5 \%$ & $6.85^{a b c}$ & $69.0^{d}$ & $223.5^{a b}$ & $5.40^{\mathrm{a}}$ & $85.0^{b}$ & $34.5^{b}$ & $238.17^{\mathrm{a}}$ & $12.48^{c}$ & $151.66^{b c}$ \\
\hline$R C+R B$ & B 1.0\% & $8.38^{a}$ & $42.67^{\mathrm{e}}$ & $228.5^{a b}$ & $3.89^{b}$ & $45.73^{c}$ & $20.25^{c}$ & $224^{b}$ & $11.5^{\mathrm{c}}$ & $115.0^{d}$ \\
\hline L.SD & 0.05 & 0.23 & 7.082 & 10.36 & 1.25 & 30.30 & 12.32 & 9.44 & 11.28 & 25.45 \\
\hline
\end{tabular}

Heavy metal uptake by canola plants was decreased by the application of RB, $\mathrm{RC}$ and the mixtures of RB and RC as compared with the untreated soil. The clear interaction between the RB and RC enhances heavy metal immobilization. Mahmoud (2011) found that the reduction of $\mathrm{Cd}, \mathrm{Pb}$ and $\mathrm{Zn}$ uptake in the root and shoot of canola plants with the addition of rice straw compost to contaminated soil. The organic matter was the most effective for heavy metal immobilization by surface complexion and adsorption. The decrease in the phytoavailability of metals in the presence of organic amendments is often attributed to the increased complexation of the metal by organic constituents (Adriano 2001and Bolan et al., 2003). Addition of compost to contaminated soils has been used for many centuries to enhance revegetation, improve soil fertility, and decrease the plant availability of toxic metals (de Souza et al., 2013). The addition of organic amendments to soils can decrease the heavy metal bioavailability by transforming them from bioavailable forms to the fractions associated with OM or metal oxides or carbonates (Walker et al., 2004).

\section{CONCLUSION}

The results of this study have confirmed the ability of RB when used alone or mixed with RC to decrease the heavy metals uptake by canola plants grown in the contaminated soils. The soil treated with mixtures of RB + RC gave the highest canola growth. The addition of the mixtures of $R B+R C$ resulted in more pronounced immobilize heavy metals as compared with RB and RC only. Therefore, it is proposed that a RB $+\mathrm{RC}$ application to contaminated soils might be a promising method for remediation of heavy metals contaminated soils. The use of spectroscopic analysis observed the precipitation, inner-sphere complex reaction and electrostatic attraction are the dominating mechanism for heavy 
metals immobilization with organic amendments.

\section{ACKNOWLEDGEMENTS}

The authors thank the Laboratory of Soil and Water Sciences, Agriculture Faculty, Tanta University, Egypt, for their assistance during this work.

\section{REFERENCES}

Abd El-Salam, M.H. (1994). Distribution of different fractions of heavy metals in industrially polluted and non-polluted soils of Egypt. M.Sc Thesis. Fac. of Agric., Ain Shams Univ., Egypt.

Adriano, D.C., W.W. Wenzel, J. Vangronsveld and N.S. Bolan (2004). Role of assisted natural remediation in environmental cleanup. Geoderma 122: 121-142. DOI:10.1016/j.geoderma. 2004.01.003.

Ahmad, M., Y. Hashimoto, D.H. Moon, S.S. Lee and Y.S. OK (2012a). Immobilization of lead in a Korean military shooting range soil using eggshell waste: an integ rated mechanistic approach. J Hazard Mater 209-210:392:401.

Alloway, B.J. (1990). Heavy metals in soils. John Wiley and Sons, Inc. New York, ISBN 0470215984 EC (1999). Integrated Pollution Prevention and Control (IPPC) Best available techniques reference document on the production of iron and steel. Publ: EC European IPPC Bureau 370.

Almaroai,Y.A., A.R.A. Usman, M. Ahmad, D.H. Moon, J.S. Cho, Y.K. Joo, C. Jeon, S.S. Lee and Y.S. Ok (2014). Effects of biochar, cowbone, and eggshell on $\mathrm{Pb}$ availability to maize in contaminated soil irrigated with saline water. Environ Earth Sci 71(3):12891296.

Asagi, N., H. Ueno and A. Ebid (2007). Effects of sewage sludge application on rice growth, soil properties and $\mathrm{N}$ fate in low fertile soil. Intl. J. Soil Sci. 2: 171-181.
Basta, N.T., J.A. Ryan and R.L. Chaney (2005). Trace element chemistry in residual- treated soils: key concepts and metal bioavailability. Journal of Environ- mental Quality.34:49-63.

Beesley, L., E. Moreno-Jime'nez, J.L. Gomez-Eyles, E. Harris, B. Robinson and T. Sizmur (2011). A review of biochars' potential role in the remediation, revegetation and restoration contaminated soils of. Environmental Pollution 159:32693282.

Black, C.A., D.D. Evans, L.E. Ensminger, J.L. White and F.E. Clark (1983). Methods of soil. analysis, Part 2, 2nd edn., Ch. 8, 18. Amer. Soc. Agronomy No.9: Madison, Wisconsin, USA.

Bolan, N.S., D.C. Adriano and D. Curtin (2003). Soil acidification and liming interactions with nutrient and heavy metal transformation and bioavailability. Advances in Agronomy 78: 215-272. DOl.org/10.1016/S00652113 (02)78006-1.

Cao, X. and W. Harris (2010). Properties of dairy-manure-derived biochar pertinent to its potential use in remediation. Bioresource Technology 101: 52225228.

DOI.org/10.1016/j.biortech.2010.02.052.

Cao, X.D., L.N. Ma, B. Gao and W. Harris (2011). Dairy-manure derived biochar effectively sorbs lead and atrazine. Environmental Sciences Technology 43: 285-3291. DOI: 10.1021/es803092k.

Chen, B., D. Zhou and L. Zhu (2008). Transitional adsorption and partition of nonpolar and polar aromatic contaminants by biochars of pine needles with different pyrolytic temperatures. Environ Sci Technol 42:5137-5143.

Cottenie, A., P.M. Verloo, L. Kiekens, G. Velghe and R. Camerlynck (1982). "Chemical Analysis of Plants and Soils". Lab. Anal and Agrochem., State Univ., Gent Belgium. pp. 63. 
de Souza, R.G., D.K.A. da Silva, C.M.A. de Mello, B.T. Goto, F.S.B. da Silva, E.V.S.B. Sampaio and L.C. Maia (2013). Arbuscular mycorrhizal fungi in revegetated mined dunes. Land Degradation \& Development 24:147155. DOI: 10.1002/ldr.1113.

Dong, X., L.Q. Ma, Y. Zhu, Y. Li and B. Gu (2013). Mechanistic investigation of mercury sorption by brazilian pepper biochars of different pyrolytic temperatures based on X-ray photoelectron spectroscopy and flow calorimetry. Environmental Sciences Technology 47:12156-12164. DOI: $10.1021 /$ es 4017816.

EL- Shall (2010). Studies on the pollution by heavy metals in some adjacent soils to factories at EL-Gharbia Governorate, Egypt. Ph.D. Thesis Faculty of Agriculture Tanta University, Egypt.

EPA, Environmental Protection Agency of USA. (1993). Standards for the use or isposal of sewage sludge final rules. Federal Register Part II, 40 CFT Part 257.

Fellet, G., L. Marchiol, G. Delle Vedove and A. Peressotti (2011). Application of biochar on mine tailings: effects and perspectives for land reclamation. Chemosphere 83:1262- 127 DOI: 10.1016/j.

Fellet, G., M. Marmiroli and L. Marchiol (2014). Elements uptake by metal accumulator species grown on mine tailings amended with three types of biochar. Sciences Total Environmental 468-469. DOI: 10.1016/j.scitotenv. 2013.08.072.

Gisbert, C., R. Clemente, J. NavarroAvino, C. Carlos Baixauli, A. Giner, R. Serrano, D.J. Walke and M.P. Pilar Bernal (2006). Tolerance and accumulation of heavy metals by Brassicaceae species grown in contaminated soils from Mediterranean regions of Spain. Environ. Exp. Bot. 56: 19-26.
Han, Y., A.A. Boateng, P.X. Qi, I.M. Lima and J. Chang (2013). Heavy metal and phenol adsorptive properties of biochars from pyrolyzed switchgrass and woody biomass in correlation with surface properties. J Environ Manag 118:196-204.

Hartley, W., N.M. Dickinson, P. Riby and N.W. Lepp (2009). Arsenic mobility in brownfield soils amended with green waste compost or biochar and planted withMiscanthus. Environ. Pollut. 157:2654-2662.

Harvey, C., M. Maclean, J. Gordon and E. Shaw (2011). Andrew Carnegie and the Foundations of Contemporary Entrepreneurial Philanthropy. Business History, 53(3): 425-450.

Houben, D., L. Evrard and P. Sonnet (2013 b). Beneficial effects of biochar application to contaminated soils on the bioavailability of $\mathrm{Cd}, \mathrm{Pb}$ and $\mathrm{Zn}$ and the biomass production of rapeseed (Brassica napus L.). Biomass Bioenergy 57: 196-204. DOl.org/10.1016/j.biombioe. 2013.07.019.

Houben, D., L. Evrard and P.H. Sonnet (2013). Beneficial effects of biochar application to contaminated soils on the bioavailability of $\mathrm{Cd}, \mathrm{Pb}$ and $\mathrm{Zn}$ and the biomass production of rapeseed (Brassica napus L.). Biomass and bioenergy DOl.org/10.1016/ j.biombioe.2013.07.019.

Houben, D., L. Evrard and P. Sonnet (2013a). Mobility bioavailability and pH-dependent leaching of cadmium, zinc and lead in a contaminated soil amended with biochar. Chemosphere 92:450-1457. DOI: 10.1016/ j.chemosphere.2013.03.055.

Jiang, J., R. K. Xu, T. Y. Jiang and Z. Li (2012a). Immobilization of $\mathrm{Cu}$ (II), $\mathrm{Pb}$ (II) and $\mathrm{Cd}$ (II) by the addition of rice straw derived biochar to a simulated polluted Ultisol, J. Hazard. Mater., 229-5230: 145-150. 
Keiluweit, M., P.S. Nico, M.G. Johnson and M. Kleber (2010). Dynamic molecular structure of plant biomassderived black carbon (Biochar). Environmental Science \& Technology 44(4): 1247-1253.

Kelly, J., I. Thornton and P.R. Simpson (1996). Urban geochemistry: a study of influence of anthropogenic activity on heavy metal content of soils in traditionally industrial and nonindustrial areas of Britain. Applied Geochemistry11:363 - 370.

Klute, A. (1986). Water retention: Laboratory methods. Methods of soil analysis Part1. 2nd., pp: 635-662. Madison, WI: ASA and SSSA.

Liang, B., J. Lehmann, D. Solomon, J. Kinyangi, J.O. Grossman, B. Neill, J.O. Skjemstad, J. Thies, F. J. Luizão, J. Petersen and E.G. Neves (2006). Black carbon increases cation exchange capacity in soils. Soil Science Society of America Journal 70:1719-1730. DOI:10.2136/sssaj2005.0383.

Lu, H., Y.Y. Zhang, X. Huang, S. Wang and R. Qiu (2012). Relative distribution of $\mathrm{Pb}^{2+}$ sorption mechanisms by sludge-derived biochar. Water Research 46:854 - 862. DOI:10.1016/j.watres.2011.11.0.

Lu, K., X. Yangb, J. Shenb, B. Robinsonc, H. Huangd, D. Liua, N. Bolane, J. Peib and H. Wanga (2014). Effect of bamboo and rice straw biochars on the bioavailability of $\mathrm{Cd}, \mathrm{Cu}, \mathrm{Pb}$ and $\mathrm{Zn}$ to Sedum plumbizincicola. Agriculture, Ecosystems and Environment 191:24-132. DOI: 10.1016/j.jenvman.2016.05.068.

Mahmoud, E. and N.A. El-Kader (2014). Heavy metal immobilization in contaminated soils using phosphogypsum and rice straw compost. Land Degradation \& Development 26: 819-824. DOI:10.1002/ Idr.2288.

Mahmoud, E.K. and A.D. Ghoneim (2016). Effect of polluted water on soil and plant contamination by heavy metals in El-Mahla ElKobra, Egypt.Solid Earth, 7: 703-711, DOI:10.5194/se-7703-2016.

Mahmoud, E.K. (2011). Heavy metal reductions in soils amended with compost and water treatment residuals. Compost Science \& Utilization 19:69-73.

Moon, D.H., J.W. Park, Y.Y. Chang, Y.S. Ok, S.S. Lee, M. Ahmad, A. Koutsospyros, J.H. Park and K. Baek (2013). Immobilization of lead in contaminated firing range soil using biochar. Environ Sci Pollut Res 20:8454-8471.

Mulligan, C.N., R.N. Yong and B.F. Gibbs (2001). Remediation technologies for metal-contaminated soils and groundwater: an evaluation. Engineering Geology 60: 193:207.

Neilson, S. and N. Rajakaruna (2014). Phytoremediation of agricultural soils: using plants to clean metalcontaminated arable lands. In A. Ansari, S. S. Gill, \& G. R. Lanza (Eds.), Phytoremediation: management of environmental contaminants (pp. 159168).

Nelson, D.W. and L.E. Sommers (1996). Total carbon, organic carbon, and organic matter. In: Methods of Soil Analysis, Part 2, 2nd ed., A.L. Page et al., Ed. Agronomy 9:961-1010. American Society of Agronomy, Inc.

Nriagu, J.O. and J. Pacyna (1991). Quantitative Assessment of Worldwide Contamination of Air, Water and Soil by Trace Metals. Nature 333: 134-139. DOI: 10.1038/333134a0.

Page. A.L. (ed.) (1982). Method of Soil Analysis, part 2, Chemical and Microbiological Properties, Second edition, American Society of Agronomy, Inc. Soil Science Society of America, Inc., Pubilisher, Madison. Wisconsin, USA. 
Park, J.H., G.H. Choppala, N.S. Bolan, J.W. Chung and T. Chuasavathi (2011). Biochar reduces the bioavailability and phytotoxicity of heavy metals. Plant Soil 348:439-451. DOI: 10.1007/s11104-011-0948-y.

Rhoades, R.L. (1954). Diagnosis and improvement of saline and alkali soils. USDA Agriculture Handbook, No. 60 US Gov. Printing office: Washington.

Roy, M. and L.M. McDonald (2015). Metal uptake in plants and health risk assessments in metal-contaminated smelter soils. Land Degradation \& Development 26: 785-792. DOI:10.1002/ldr.2237.

Schmidt, U. (2003). Enhancing phytoextraction: the effect of chemical soil manipulation on mobility, plant accumulation, and leaching of heavy metals, Journal of Environmental Quality, 32(3): 1939-1954.

Sruthy and Jayalekshmi (2014). Electrokinetic Remediation of Heavy Metal Contaminated Soil International Journal of Structural and Civil Engineering Research.

Tong, X.J., J.Y. Li, J.H. Yuan and R.K. Xu (2011). Adsorption of $\mathrm{Cu}$ (II) by biochars generated from three crop straws. Chemical Engineering Journal 172(2-3): 828-834. DOl.org/10.1016/ j.cej.2011.06.069.

Uchimiya, M., I.M. Lima, K.T. Klasson and L.H. Wartelle (2010). Contaminant immobilization and nutrient release by biochar soil amendment: Roles of natural organic matter. Chemosphere 80: 935-940. DOI: 10.1016/ j.chemosphere. 2010.05.020.

Vangronsveld, J. and S.D. Cunningham (1998). Introduction to the concepts. In Metal contaminated soils: in situ inactivation and phytorestoration, Vangronsveld J, Cunningham SD (eds). Springer: Berlin; 1-15.
Walker, D.J., R. Clemente and M.P. Bernal (2004). Contrasting effects of manure and compost on soil $\mathrm{pH}$, heavy metal availability and growth of Chenopodium album $L$. in a soil contaminated by pyritic mine waste. Chemosphere 57: 215-224.

Wu, W., M. Yang, Q. Feng, K. McGrouther, H. Wang, H. Lu and Y. Chen (2012). Chemical characterization of rice straw-derived biochar for soil amendment, Biomass Bioenergy 47: 268-276. DOI.org/10.1016/j.

Xu, X., X. Cao and L. Zhao (2013). Comparison of rice husk- and dairy manure-derived biochars for simultaneously removing heavy metals from aqueous solutions: role of mineral components in biochars. Chemosphere 92: 955-961. DOl.org/10.1016/ j.chemosphere.2013.03.009.

Xu, X.Z., F. Chien, A. Butler, L. Salkoff and C. Montell (2000). TRPgamma, a Drosophila TRP-related subunit, forms a regulated cation channel with TRPL. Neuron 26(3): 647--657.

Yuan, J., R. Xu, N. Wang and J. Li (2011). Amendment of acid soils with crop residues and biochars', Pedosphere, 21:302-308.

Yuan, J.H. and R. K. Xu (2011). The amelioration effects of low temperature biochar generated from nine crop residues on an acidic Ultisol. Soil Use and Management, 27: 110-115.

Zheng, R., G. Sun, C. Li, J. Brian, Z. Xie, B. Zhang and Q. Wang (2017). Mitigating cadmium accumulation in greenhouse lettuce production using biochar. Environmental Science and Pollution Research DOI 10.1007/s11356-016-8282-9. 
تأثير إضافة كلا من البيوشار والكمبوست المصنوع من قش الأرز بنسب مختلفة على

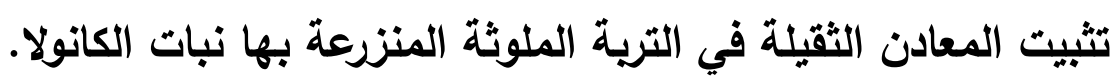

$$
\begin{aligned}
& \text { عيسوى قاسم محمود (1) ، محمود محمد إبراهيم(") ، نهال على (") ، } \\
& \text { حنان محمد على (1) } \\
& \text { (1) قسم علوم الأراضى وإلمياه - كليه الزراعة - جامعة طنطا. }
\end{aligned}
$$

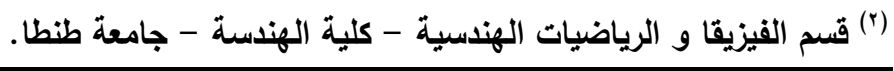

$$
\begin{aligned}
& \text { الملخص }
\end{aligned}
$$

تساهم الأنثطة الصناعية في تراكم المعادن الثقيلة في التربة ، والتي يمكن أن تهاد صحة الإنسان وإنتاجية

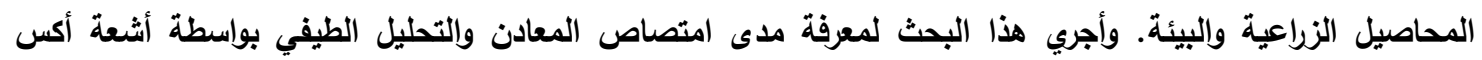

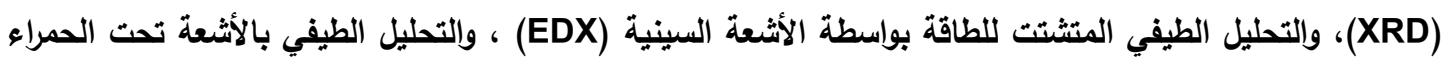

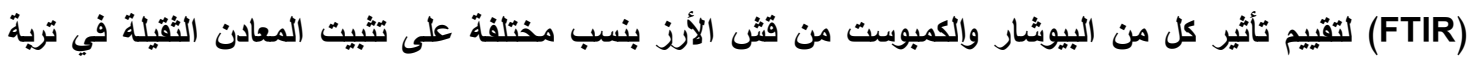

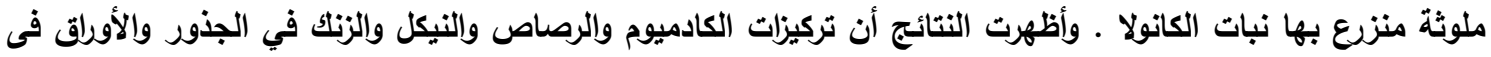

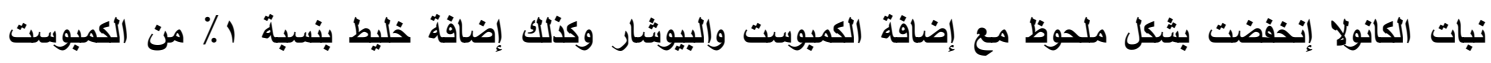

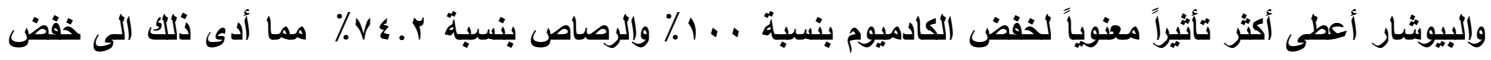

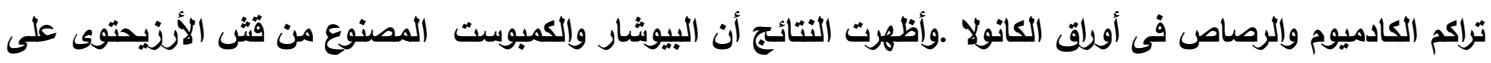

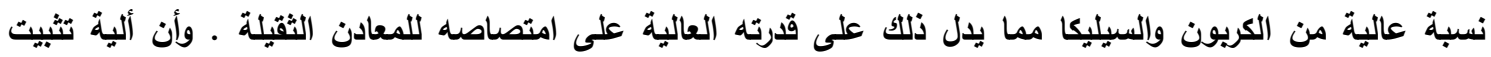

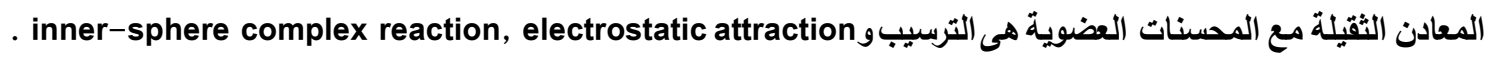
وأتضح من ذلك أن تثبيت المعادن الثقيلة فى التربة بواسطة المحسنات العضوية من الطرق الحيوية والفعالة فى معالجة الأراضى الملوثة من فئة 
E. K. Mahmoud, et al., 